\title{
MEMBANGUN PARTISIPASI MASYARAKAT MISKIN DALAM PENGUATAN DEMOKRASI DI PROVINSI DAERAH KHUSUS IBUKOTA JAKARTA
}

\author{
Oleh: Rahmatullah*
}

\begin{abstract}
The existence of a democratic system is strongly influenced by the participation of all parties, including the poor. So far, the poor always associated as apathetic and irrational in politics. and consider any political change will not be much change their fate. However, in the case of DKI Jakarta showed that they are a group of rational, transparent, and participatory enough in politics, though not to the extent that satisfactory. Their knowledge of politics obtained directly from a variety of media and existing facilities. Because it is necessary for the political strengthening of the urban poor, in the form of strengthening the political culture of the participants, which puts them have a real orientation of the systems, structures and processes of political and administrative.. That way they can be involved in a variety of policies oriented towards the improvement of people's lives rate. The phenomenon of the political life of the urban poor is not merely seen from political participation in the form of political activity, but also a social activity
\end{abstract}

Key Words: Poor, participation, democracy.

\section{Pendahuluan}

Reformasi di Indonesia mengandung makna demokratisasi sebagai agenda politik pembangunan negara yang tengah menghadapi krisis dan transisi pasca tumbangnya kekuasaan Orde Baru. Dengan demokrasi maka ditengarai bahwa Indonesia bisa menanggulangi kemiskinan sebab demokrasi memberi ruang partisipasi kelompok miskin untuk mendorong kebijakan publik yang terkait dengan pembangunan kesejahteraan, sehingga dengan kata lain demokratisasi sebagai prasyarat negara mengurangi kemiskinan atau kemelaratan.

\footnotetext{
* Dosen Universitas Indraprasta PGRI Jakarta, dan anggota Komite Pemuda pada Konfederasi Serikat Pekerja Indonesia
} (DPN KSPI)

Demokrasi sebagai sistem politik mensyaratkan partisipasi politik dalam arti bagaimana mengartikulasikan pelibatan berbagai kelompok masyarakat yang plural, termasuk masyarakat miskin di dalamnya agar dapat bersinergi dalam merencanakan dan melaksanakan pembangunan. Pembangunan dalam konteks politik demokrasi adalah terbukanya ruang publik yang bebas dalam menginisiasi tindakan bagi masyarakat untuk peneguhan legitimasi atau dalam proses pengambilan keputusan umum.

Dalam pemikiran inilah, maka demokrasi lebih sebagai alat atau cara (means/instrument) dari pada sekedar
omite Pemuda pada Konfederasi Serikat Pekerja Indonesia 
tujuan akhir (ends/goals) dari pembangunan negara. Bagi kelompok masyarakat miskin, demokrasi membebaskan mereka dari peminggiran politik untuk ikut serta dalam proses pengambilan keputusan yang dapat menentukan kesejahteraan atau nasib masa depannya.

\section{Konsepsi Masyarakat Miskin Dalam Konteks Pembangunan}

Dalam pelbagai literatur kajian mengenai kemiskinan dapat diklasifikasi dalam tiga pendapat dominan, yakni: pertama; faktor kebijakan, yaitu kondisi kemiskinan yang dialami oleh suatu komunitas masyarakat disebabkan kebijakan negara, sehingga tidak adanya kesempatan pelibatan dan pengakuan hakhaknya untuk menentukan aspirasi dan inisiatifnya dalam pembangunan (Davies, 1976) yang lazim disebut kemiskinan struktural (Soemardjan \& Alfian, 1980). Kedua; faktor kebudayaan, yakni kemiskinan akibat penghayatan nilai-nilai kultural yang membentuk dalam perilaku kehidupan masyarakat. Dan, ketiga; faktor alam (natural) atau lingkungan fisik yang tidak memungkinkan masyarakat untuk memperoleh kehidupan yang layak.

Menurut John Haba dalam Hisyam (2001;135) memandang kemiskinan struktural di Indonesia terkait dengan cara pandang kemiskinan relatif yakni diukur dan dipahami berdasarkan perbandingan antara pendapatan suatu kelompok masyarakat dengan tingkat pendapatan kelompok masyarakat lainnya sehingga diketahui suatu kelompok tersebut dikategorikan kaya atau mampu, dan kategori lainnya miskin yang menunjukkan kesenjangan ekonomi. Adapun kemiskinan struktural dimaksudkan suatu kondisi kemiskinan yang ditentukan dengan menetapkan garis tingkat pendapatan minimum tertentu. Dengan Model Proxy Mean Test (PMT) dengan memperkirakan pengeluaran penduduk melalui variabel nonmaterial, seperti kondisi fisik bangunan, dan sebagainya, dimana kriteria miskin ditentukan sesuai Pendapatan Perkapita/Bulan, yakni Rp. 447,797/Bulan pada tahun 2014 (naik dari sebelumnya, tahun 2013 sebesar Rp. 434,322/Bulan, dan tahun 2012 sebesar392,571/Bulan). Merunut data di BPS DKI Jakarta (Data TNP2K yang masih menggunakan data 2011, karena 3 tahun sekali diperbarui, namun 2014 tertunda akibat suksesi politik sampai 2015) tercatat sebanyak 286,075 Rumah Tangga Miskin (Bukan Kepala Keluarga) sehingga dari $40 \%$ penduduk miskin di Indonesia, DKI terendah secara nasional (BPS DKI Jakarta, 2014).

Kemiskinan struktural yang merupakan dampak dari kebijakan "buatan" kekuasaan manusia disebabkan keberpihakan pemerintah sebagai 
pengambil kebijakan yang mengakomodasi kelompok pemilik modal atau kelompok kaya dan kemudian berakibat pada timpangnya pendistribusian aset-aset ekonomi produksi pada kelompok masyarakat ekonomi lemah. Berkenaan dengan hal tersebut pemerintah pula yang membuat kriteria suatu keluarga miskin sesuai ukuran kebutuhan dasar, penghasilan, aktifitas sosial, keterjangkauan pelayanan sosial, kepemilikan alat rumah tangga dan sarana hiburan, serta kemampuan lainnya sebagai dasar untuk mengatasi kemiskinan melalui sejumlah program yaitu: pertama; pemberdayaan keluarga miskin melalui kegiatan-kegiatan penyuluhan dan bimbingan motivasi serta keterampilan berusaha. Kedua; melalui kemitraan usaha, dimana keluarga miskin dimasukkan dalam Kelompok Usaha Bersama yangterkait dengan program-program Penanganan Keluarga Miskin, dengan memberikan bantuan usaha ekonomi produktif. Ketiga; melalui partisipasi masyarakat, baik pemerintah selaku pembina dibantu masyarakat sekitar dimana program tersebut diselenggarakan sehingga dengan pelibatan masyarakat yang mampu dan pemerintah sebagai "bapak angkat" maka beban penanggulangan kemiskinan lebih "murah" dari pada harus dikerjakan satu instansi saja (John Haba, 2001;135).
Tampaknya pendekatan partisipasi dari segi sosial dan ekonomi di atas perlunya sebuah pendekatan politik mengingat partisipasi juga dimaknai adanya proses yang komunikatif dalam masyarakat yang menjunjung kesetaraan. Konteks demokrasi yang substansinya adalah pengakuan hak-hak bebas yang sama dan setara untuk membangun komunikasi yang inklusif dan membuat konsensus bersama. Sebab dalam partisipasi dimana terdapat relasi posisi antara kelompok relasi "kuasa" dan yang dikuasai maka melahirkan konsensus yang bias atau cenderung pada kelompok kepentingan dominan. Demokrasi menuntut adanya partisipasi yang setara dimana kekuasaan terdistribusi secara merata dengan hak yang sama.

Sejatinya demokrasi yang diagendakan dari produk gerakan reformasi di Indonesia adalah membuka kesempatan bagi kelompok masyarakat miskin di dalam pengambilan keputusan. Partisipasi politik kelompok masyarakat miskin bukan sekedar sebuah pilihan (vote), tetapi juga dari segi keikutsertaannya dalam bersuara menyampaikan aspirasinya (voice), dan termasuk juga mendiskusikan hingga memonitor hasil kebijakan yang disusun oleh institusi demokrasi. Karenanya pula diperlukan penyikapan politik dari masyarakat miskin di tengah tempaan arus 
demokratisasi, khususnya di ranah Ibukota Jakarta.

\section{Demokratisasi dan Politik Masyarakat Miskin Kota}

Inti perkataan demokrasi adalah kehidupan bersama dalam sistem bernegara dengan pelibatan setiap orang dalam pengambilan keputusan. Bahwa semua anggota kelompok masyarakat bebas menyampaikan aspirasinya atau kemauannya secara demokratis untuk dikalkulasi dalam keputusan politik yang demokratis. Dengan demikian kelompok minoritas di parlemen atau kelompok marginal di luar parlemen memiliki hak untuk menggalang opini politik ataupun ruang opini publik untuk memperjuangkan aspirasinya secara demokratis.

Smith dan Lindeman (1955) dalam Labolo (2011;145-146) demokrasi dipilih sebagai landasan pemikiran suatu negara setidaknya memiliki arti: pertama, ia merujuk pada kepentingan mayoritas. Mayoritas seringkali mengklaim mewakili kelompok secara keseluruhan, walau kenyataannya tidak semuanya. Mayoritas sebagai representasi rakyat secara keseluruhan adalah dengan pertanggungjawaban, sehingga mayoritas bertanggungjawab sebagai atas nama bersama. Kedua, memberikan kekuatan bagi kelompok minoritas untuk mengimbangi kekuatan mayoritas. Di sinilah peran pentingnya dimana minoritas merupakan bagian dari mayoritas secara keseluruhan diatur tanpa rasa takut, dan bahkan menjadi mayoritas atau minoritas hanyalah sekedar perputaran atau pergeseran pada waktunya. Sehingga mayoritas membutuhkan kelompok penyeimbang dari kelompok minoritas untuk menutupi ketidak-sempurnaannya dalam mengelola pemerintahan, dan sebaliknya minoritas membutuhkan legitimasi dari kelompok mayoritas untuk menjamin ketersediaan fasilitas jaminan dan kenyamanan dalam kehidupan bersama. Ketiga, demokrasi mendorong setiap orang untuk mendapat manfaat dari kualitas kepemimpinannya. Demokrasi selain sebagai mekanisme yang mendorong kuantitas juga memberikan kesempatan luas dan legitimasi bagi kualitas individual untuk memimpin.

Dalam kaitannya dengan demokratisasi maka mekanisme perwujudan demokrasi diejawantahkan melalui berbagai proses penataan yang memungkinkan berbagai aspirasi kelompok masyarakat me-nyalurkan tuntutan dan aspirasinya dalam institusi demokrasi sehingga terbangun keputusan bersama. Kajian dari Arifin dalam Jurnal Analisis $\quad$ Sosial $\quad(2002 ; 191-192)$ mengungkap bahwa praktik-praktik demokratisasi yang dirasakan manfaatnya bagi kelompok masyarakat miskin di antaranya (salah satunya) dalam mengkaji 
dampak program kemiskinan, yakni apakah praktik partisipasi lebih berfungsi sebagai alat pengelolaan program yang efektif dan efisien ataukah lebih sebagai alat pemberdayaan kelompok miskin, termasuk di dalamnya penguatan organisasi kelompok miskin agar mampu berfungsi sebagai wadah menyalurkan dan membela hak dan kepentingannya? Sebab jika yang pertama yang menonjol maka prinsip demokrasi yang terwujud dalam mekanisme partispatif telah gagal menunjukkan kekuatannya dalam memberikan kesempatan keberdayaan kaum miskin sebagai upaya penanggulangan kemiskinannya.

Memperbincangkan masyarakat miskin dari sudut pandang politik umumnya dijejali oleh kesan sebagai kelompok masyarakat yang kurang peduli terhadap perkembangan politik atau bersikap apatis (bahkan apolitik) karena disibukkan oleh aktivitas seputar pemenuhan kebutuhan ekonomi seharihari. Pandangan pragmatis kelompok miskin menganggap politik hanyalah "pekerjaan" segolongan elit yang kerap senang "beretorika" dan menghampiri kaum miskin untuk kepentingan sesaat. Termasuk pula kelompok masyarakat miskin dalam pandangan politik praktis hanya "dimanfaatkan" untuk partisipasi politik secara mobilisasi dalam memberikan dukungan atau penolakan atas suatu dorongan kepentingan kaum elit.

Namun di era global dengan majunya teknologi informasi yang kian mempertontonkan area politik (termasuk pelaku institusi/negara) yang mengikis ketabuan, maka stigma bahwa kelompok masyarakat miskin dianggap irrasional dalam politik tidaklah sepenuhnya tepat, apalagi keterbukaan dan kebebasan menjadi "angin segar" untuk menuntut kaum miskin berpartisipasi secara politik. Terutama bagi kelompok bagi masyarakat miskin perkotaan yang terbuka dengan berbagai sosialisasi dan informasi politik.

Meskipun demikian terbukanya berbagai bentuk informasi maupun wacana publik keseharian seputar kehidupan politik, namun warga miskin kota di Ibukota Jakarta belum sepenuhnya terlibat dalam budaya partisipan secara politik mengingat kepentingannya yang sesaat mendekati mereka setiap siklus lima tahunan atau hanya sekedar pilihan (vote), namun penyikapan mereka terhadap perkembangan aksentuasi politik pembangunan belum sepenuhnya terlibat secara partisipatif. Dalam arti kata aspirasi kaum miskin kota dalam melakukan tuntutan keputusan publik masih belum tampak "terdemonstrasikan" secara efektif, kecuali sekedar luapan spontanitas melalui aksi "demo" atau penolakan yang belum terorganisir aspirasinya. Misalnya 
penolakan atas penggusuran, masalah layanan kesehatan, hingga mempersoalkan pembangunan fisik di sekitar lingkungan yang berdampak terhadap eksistensi kelompok miskin tertentu.

Mengingat pengetahuan atau informasi dan wacana seputar politik menjadi isu keseharian bagi warga Ibukota sehingga membentuk preferensi politik tertentu namun kebanyakan kelompok warga masyarakat miskin kota tidak begitu tertarik politik bukanlah dianggap bagian dari kehidupannya dan hanya membuang waktu yang tidak bermanfaat bagi pemenuhan kebutuhan hidup sehari-hari. Selain itu politik dianggap sebagai kehidupan yang penuh jebakan dan intrik, terutama menyangkut perebutan sumber daya atau kekuasaan. Sehingga kelompok masyarakat miskin DKI Jakarta tidak tertarik untuk mengikuti aktivitas politik atau beraktualisasi dalam dinamika politik perkotaan, kecuali bagi mereka keikutsertaannya hanyalah sebatas pada pemberian dukungan suara. Sikap politik warga kelompok ini lebih didasari pada dukungan partisipasi yang penuh rasa simpati tertentu dari pada sikap secara rasio dan kritis untukmendorong bekerjanya sistem politik. Sebab bagi kelompok ini disadari sepenuhnya bahwa partisipasi mereka sekedarnya dan tidak berorientasi pada "perebutan" kekuasaan ataupun untuk ikut terlibat dalam proses pemerintahan maupun parlemen.

Tidak jarang pula dijumpai bahwa kelompok warga miskin ini lebih mudah didekati oleh elit politik untuk menjadi basis dukungan dengan berbagai atribut atau posko dilengkapi simbol-simbol politik tertentu yang hadir di tengah kehidupan permukiman mereka. Termasuk juga berbagai ungkapan dukungan terbuka melalui lefleat atau spanduk, umbulumbul, hingga banjir undangan kegiatan perkumpulan warga, kelompok pengajian, hingga PKK, urusan lomba maupun arisan. Fenomena yang cukup menjadi rahasia umum adalah adanya hubungan patronase politik antara elit politik dengan kelompok warga miskin kota melalui bantuan materi dengan imbalan dukungan. Dengan demikian keterlibatan mereka dalam partisipasi politik terkesan sebagai kompensasi dari apa yang telah diterimanya yang sudah menjadi realita politik. Terlebih lagi kelompok masyarakat miskin kota umumnya non ideologis dalam menentukan preferensi politiknya, kecuali sekedar sebagai solidaritas sosial sesama kelompoknya yang dilatari oleh kondisi sosio budaya maupun ekonomi, sehingga mudah dipengaruhi oleh kepentingan elit politik ataupartai politik untuk mendulang perolehan suara dan bahkan dalam kondisi tertentu dapat dimanfaatkan oleh politisi partai politik untuk memaksimalkan massa 
loyalis yang sewaktu waktu mudah digerakkan dengan mempertahankan budaya politik subjektif.

Dalam konteks inilah diperlukannya penguatan politik bagi masyarakat miskin kota yakni penguatan budaya politik partisipan yaitu suatu bentuk budaya yang anggota kelompok masyarakatnya cenderung memiliki orientasi nyata terhadap sistem, struktur dan proses politik serta administrasi. Dengan kata lain menurut kajian Almond dan Verba (1963) bahwa dalam budaya politik partisipan, tiap anggota masyarakat memiliki kesadaran politik, perhatian, dan kepedulian terhadap objek politik (sistem dan proses politik). Dengan kata lain budaya politik partisipan adalah perilaku individu yang mampu menyeimbangkan pada tataran kognisi dan afeksi politik dalam merespon fenomena politik yang dihadapi.

Terkait budaya politik tersebut, turut pula ditentukan oleh sikap politik anggota masyarakat yang membentuk kualitas partisipasi politiknya. Kualitas partisipasi seseorang ditentukan oleh orientasi politiknya yang didasarkan pada kondisi dan latar belakang sosial, budaya dan ekonomi sekitarnya. Inilah yang dijadikan pijakan untuk membentuk preferensi politik berupa pilihan politik dengan pertimbangan nilai-nilai dalam merespon lingkungan yang dihadapi, baik berupa sikap atau tindakan dalam menentukan dukungan.

Meski demikian, fenomena kehidupan politik kelompok masyarakat miskin kota tidak semata dilihat dari partisipasi politik dalam bentuk aktivitas politiknya, mengingat terdapat kelompok miskin kota yang memiliki akses informasi politik yang cukup melalui aktivitas sosial, meski bukan dikatakan aktivitas politik, melalui keikutsertaannya secara aktif dalam kegiatan kemasyarakatan atau organisasi keagamaan semisal organisasi buruh, Dewan Mesjid, NU. Muhammadiyah dan sebagainya tentu memiliki preferensi politik sesuai sistem nilai atau keyakinan politik yang mendorongnya berpartisipasi politik secara rasional.

\section{Masyarakat Miskin dalam Partisipasi Politik Demokrasi di Ibukota Jakarta}

Kesuksesan demokrasi adalah tidak sekedar bagaimana keberhasilan pelaksanaan prosedur demokrasi bernama Pemilu dengan diikuti oleh mayoritas warga masyarakat pemilihnya, namun lebih dari proses tersebut adalah terbentuknya institusi demokrasi yang mewakili dengan memberikan kesempatan atau ruang secara timbal balik berupa input dan output politik yang terbuka, termasuk mendorong kritik dan oposisi. Untuk mendorong perilaku politik demikian 
adalah meningkatkan kualitas pemilih secara rasional.

Pasca reformasi, di Propinsi Daerah Khusus Ibukota Jakarta yang mayoritas warganya masih kelompok warga miskin tersebar diberbagai wilayah Kota dan Kabupaten Administrasi dilihat dari kependudukan dan pola permukimannya yang semrawut (tidak teratur), namun dalam setiap kontestasi politik Pemilu lima tahunan cukup memberikan dampak perubahan bagi penempatan elit dalam posisi politik di parlemen (bahkan juga pada level eksekutif). Meskipun perilaku politik kaum miskin belum sepenuhnya berada pada tataran budaya politik partisipan sesungguhnya, namun keikutsertaannya membawa dampak bagi keputusan umum. Bahkan sikap politik warga Jakarta dari berbagai lapisan dan golongan, oleh pelbagai kalangan dinilai sebagai masyarakat politik yang rasional dan dewasa terhadap demokrasi. Walaupun “digempur" beragam isu rasis atau SARA dalam setiap Pemilu (baik Pilleg, Pilpres, maupun Pemilukada) dengan berbagai macam bentuknya (secara langsung melalui aksi, mimbar bebas, ceramah, hingga debat publik, dan secara tidaklangsung melalui opini cetak dan elektronik/media internet) tidak berpengaruh untuk bertindak melakukan "kekerasan" atau sweeping yang merusak tahapan dan tertibnya Pemilu. Termasuk, kerapkali terjadi perubahan pemilih sebagai penyikapan politiknya yang rasional sehingga warga Jakarta, termasuk warga miskin kota yang berpartisipasi secara politik, dianggap sebagai "pemilih yang selalu bergeser" alias tidak mengkuti kepakeman politik elit yang dianggapnya status quo.

Namun sebagaimana disebut di atas, partisipasi politik tidaklah cukup dengan datang dalam pemberian suara dalam Pemilu, sebab partisipasi politik secara langsung adalah meniscayakan keaktifan individu dalam aktivitas politik berupa ikut dalam debat publik, kampanye, diskusi politik, dialog, mimbar bebas untuk penggalangan dukungan hingga gerakan protes dan oposisi yang sehat. Sehingga didapati bahwa warga miskin perkotaan di Jakarta dikatakan sebagai pemilih yang rasional namun belum sepenuhnya terlibat aktif dalam perpolitikan dengan ditandai keengganannya mengikuti aktivitas politik. Namun pemilih dari kalangan masyarakat miskin di Ibukota cukup unik karena preferensi politiknya yang cukup mengingat sebaran akses informasi dan wawasan politiknya yang didapat secara langsung melalui media atau sosialisasi mendapat julukan pemilih yang mudah bergeser atau turut menjadi massa pemilih "mengambang" yang sulit ditebak. Sehingga pemberian konpensasi berupa nilai-nilai politik atau (secara kasar) 
"iming-iming" materi belum tentu menjamin memperoleh dukungan suara.

Dari berbagai pendapat mengenai kajian politik masyarakat miskin, nampaknya kajian Asrinaldi $(2012 ; 194)$ bahwa adanya masyarakat miskin yang juga turut memahami fenomena politik, ternyata tidak sepenuhnya mereka tergolong pada kelompok yang apatis yang diartikan sebagai kelompok masyarakat miskin tidak atau kurang memiliki kesadaran berpolitik kecuali turut berpartisipasi dengan cara dimobilisasi oleh faktor kekuatan yang datang dari luar. Sementara itu terdapat pula kelompok masyarakat yang semi apatis yang partisipasinya bersifat otonom, meski sebenarnya kelompok ini lebih terlihat dalam Pemilu dengan respon politik mereka memadai secara kognisi.

Dengan kata lain, kelompok masyarakat miskin kota yang tergolong semi apatis sedikit lebih baik dari segi wawasan politik, apalagi mereka yang terlibat dalam interaksi sosial secara intens berupa aktivitas sosial, sehingga dengan demikian kelompok ini patut didorong untuk memiliki afeksi politik agar turut serta terlibat aktif secara seimbang dalam wujud aktivitas politik untuk membangun penguatan basis politik warga menuju berbudaya politik partisipan, tentunya turut membangun kemandiriannya dalam berpolitik.
Hal tersebut berbeda dengan kelompok masyarakat miskin kota yang "sempurna" apatis, sebagaimana menurut Asrinaldi (2012;95) dikatakan bahwa mereka berada dalam interaksi relasi kuasa yang membangun hubungan harmoni agar terpenuhinya hasrat ekonomi atau berharap pada perbaikan keadaan nasib. Melalui relasi kekuasaan yang bersifat patronclient, mereka berharap difasilitasinya kebutuhan ekonominya sehingga model demikian ini membawa konsekwensi terpeliharanya pembentukan partisipasi masyarakat miskin yang kian apatis dalam berpolitik.

\section{Kesimpulan}

Demokratisasi meniscayakan partisipasi politik berbagai kelompok termasuk masyarakat miskin untuk membangun kemandirian dan kekuatannya secara otonom sehingga mengikis ketertutupan atau keterasingan dalam mewujudkan perubahan nasib dan pembangunan untuk masa depannya. Kelompok masyarakat miskin kota mesti menjadikan demokrasi sebagai alat yang membuka ruang kesempatan dalam memperkuat pasrtisipasinya dalam pembangunan sehingga secara perlahan meninggalkan pola kehidupan miskinnya, dan di lain sisi, pemerintah maupun elit politik atau partai politik berkewajiban turut mendorong pelibatan peran serta 
42 JURNAL ILMIAH MIMBAR DEMOKRASI

melalui pendidikan, gerakan pemberdayaan dan partisipasi secara politik untuk mengentaskan mereka dari jeratan kemiskinan/kemelaratan. Rasionalitas dan kemandirian politik akan sulit tumbuh berkembang jika masyarakatnya dalam kemiskinan dan ketergantungan. Demokrasi akan tumbuh kuat jika partisipasi independen dari masyarakat terjadi dan berimplikasi pada kemakmuran masyarakatnya.

Dengan demikian, maka kemajuan politik demokrasi sebagai sistem kenegaraan modern di era reformasi dewasa ini bukan sekedar menampilkan ironi politik berbiaya tinggi (high cost) untuk mendanai proses demokrasi disbanding biaya yang dikeluarkan untuk memberdayakan masyarakat miskin dalam upaya meningkatkan kesejahteraan mereka. Sebab reformasi sejatinya adalah menggeser perubahan perilaku masyarakat untuk menjadi pelaku demokrasi yang sesungguhnya dalam berpolitik. Masyarakat adalah aktor utama dalam politik praktis terhadap bangunan kedaulatan sekaligus penentu dalam sirkulasi kepemimpinan yang sepatutnya memihak pada kemauan umum. Bukan sebaliknya kepemimpinan hasil "kartelisasi" dalam kemasan pragmatis penuh pemanfaatan yang pada akhirnya memproduk “jaring-jaring” kebijakan (output) yang menjerat masyarakat selalu nestapa dalam pemiskinan (baca: tetap dalam kemiskinan struktural).

\section{DAFTAR PUSTAKA}

Arifin, Haswinar. 2002. Analisis Efektivitas Upaya Demokrasi Terhadap Penanggulangan Kemiskinan. Jurnal Analisis Sosial. ISSN 1411-0024. Vol. 7, No. 2 Juni 2002. Bandung: Penerbit Akatiga

Asrinaldi. 2012. Politik Masyarakat Miskin Kota. Yogyakarta: Penerbit Gava Media

Biro Pusat Statistik Propinsi Daerah Khusus Ibukota Jakarta, 2014. Angka Kemiskinan.Wawancara, 17 Desember $2014 \quad$ (Tidak Dipublikasikan).

Hisyam, Muhamad. 2001. Indonesia Menapak Abad 21 Dalam Kajian Sosial dan Budaya. Tanpa Tempat Terbit, Penerbit Peradaban

Labolo, Muhadam. 2011. Dinamika Demokrasi, Politik, dan Pemerintahan Daerah. Jakarta: PT Indeks Jakarta.

Rohman, Ainur, dkk. 2012. Partisipasi Warga Dalam Pembangunan dan Demokrasi. Malang: Averroes Press. 